\title{
GPR158 wt Allele
}

National Cancer Institute

\section{Source}

National Cancer Institute. GPR158 wt Allele. NCI Thesaurus. Code C125463.

Human GPR158 wild-type allele is located in the vicinity of 10p12.31 and is approximately $427 \mathrm{~kb}$ in leng th. This allele, which encodes probable G-protein coupled receptor 158 protein, is involved in $\mathrm{G}$ protein-coupled receptor signal transduction. 